\title{
O conceito de tecnologia sob o olhar do filósofo Álvaro Vieira Pinto
}

\begin{abstract}
Resenha da obra do autor: Pinto, Álvaro Vieira do volume I "O conceito de tecnologia- Rio de Janeiro: Contraponto, 2005, p. 1- 531. Álvaro Vieira Pinto era um filósofo que foi catedrático da Faculdade de Filosofia da então Universidade do Brasil (hoje UFRJ). Participante fundador do Instituto Superior de Estudos Brasileiro (ISEB). Nascido em 1909, falecido no ano de 1987. Além do Conceito de tecnologia nos seus volumes I e II, é preciso destacar duas de suas grandes obras: "Consciência e Realidade Nacional (volume I: A consciência Ingênua; volume II: A consciência Crítica) e Ciência e Existência: problemas filosóficos da pesquisa científica". As obras deste autor fizeram parte de um trabalho maior desenvolvido a partir da dissertação de Mestrado no Programa de Pós-Graduação em Geografia pela Universidade Federal do Rio Grande- FURG. e da atualização do propositor. A dissertação defendida em Junho/2010, sob a orientação do Professor Dr. Dário de Araújo Lima intitula-se: "Reflexões teóricas sobre os processos sociais da contradição exclusão/inclusão.
\end{abstract}

Álvaro Vieira Pinto, um filosofo Brasileiro, contempla, em uma de suas obras, uma discussão primordial a cerca do conceito de tecnologia, a qual é gerada por todos nós. A partir desse tema, a abordagem e compreensão das características da essência da formulação e constituição tornam-se de grande valia para qualquer participante da sociedade a fim do mesmo entender a potência humana e suas contradições. Ainda para o filósofo, não é possível fechar toda a estrutura do saber e fazer humano em pouquíssimas linhas, mas o ponto de partida deve ser dado. Para tanto, é preciso contextualizar, periodicizar, tornar claro a estrutura, para então compreender e analisar a totalidade, fugindo das armadilhas de um cenário armado.

Nesse caso, para dissertar a cerca do tema escolhido, poderia ter elegido outro autor mais próximo a minha área de formação, como da geografia ou até mesmo da sociologia; mas não. A ciência na qual procuro, deve ser vista pela totalidade; para isso, procuro romper paradigmas e concepções que não responderão por si só as minhas indagações, além de não contentar-me com alternativas fechadas, pois creio que essas devem, a todo instante, estar abertas ao discurso cientifico.

A obra "O conceito de tecnologia" (apresentado por Álvaro Vieira Pinto no primeiro volume sobre esse tema), aborda um homem dentro de seu processo de hominização, sob dois aspectos fundamentais: a aquisição, pela nossa espécie, da capacidade de projetar, e a conformação de um ser social, condição necessária para que se possa produzir o que foi projetado. Juntando na prática esses dois conceitos, surge o conceito de filosofia da Técnica, a qual é a arte de fazer surgir sempre algo novo; no entanto, "quantitativamente esse novo pode alcançar dimensões tão assombrosas que efetivamente 0 revistam dos aspectos qualitativamente originais". Neste contexto, o mesmo coloca a importância da "técnica como libertadora" e a recusa como um mero perigo de nossa espécie, concluindo com isso que
Alexandre E. Bandeira*

* Autor/propositor: Graduado em Geografia Plena FURG; Mestre em Geografia FURG; Tutor/bolsista (distância) no curso de especialização em Educação em Direitos Humanos, do Sistema Universidade Aberta do Brasil (UAB)/ FURG e Membro do Grupo de Pesquisa em Política Natureza e Cidade com trabalho na linha de pesquisa Observatório dos conflitos urbanos - FURG.

Geografia Ensino \& Pesquisa, v. 15, n.1 jan./abr. 2011 
sempre é o homem o construtor de seu ambiente e de sua qualidade de vida. Para ele, é um erro primordial olhar para as coisas produzidas a partir da técnica simplesmente, "pois a verdadeira finalidade da produção humana consiste na produção das relações sociais, a construção de formas de convivência". Através da filosofia, o autor percorre e pensa 0 ser nacional a partir da periferia do sistema-mundo. Nesse contexto, 0 autor defende um projeto nacional como única alternativa viável para almejar o desenvolvimento econômico, o qual engloba o propósito de rompimento de uma dinâmica, ideologicamente disseminada como universal, que é a domínio do centro da tecnologia por poucos, e onde seria reservado ao mundo da periferia a condição de "paciente receptor" das inovações técnicas. 0 filósofo defende que na fase atual já poderia se romper este cenário de obediência e promiscuidade da periferia perante o centro, através de um projeto nacional libertador.

Na sua concepção teórica, Vieira Pinto defende que no centro o crescimento industrial abrange, sob uma forma mais homogênea, produtividade e qualidade de vida para os segmentos da sociedade envolvidos com o trabalho assalariado. No entanto, na periferia, apenas segmentos privilegiados usufruem dos benefícios da relação com a industrialização do centro, especialmente segmentos exportadores de matéria-prima foram os que se beneficiaram com essa relação. Assim, o mesmo ressalta que nos segmentos espoliados há uma espécie de "consciência ingênua", um abismo, ocasionado diante das outras esferas de trabalho, assalariados ou não, gerando também a ilusão de participação da totalidade, do "mundo globalizado". A passagem do subdesenvolvimento para o desenvolvimento requer uma mudança coletiva da sociedade; uma relação entre o homem e o mundo no qual exige que cada um possa manusear a realidade com recursos cada vez mais elaborados, onde a consciência (critica) da mudança de realidade deverá partir de uma clareza da mesma, uma noção do que é necessário para se mudar e o porquê é importante promover a mudança.

O modo pelo qual o homem vê o mundo tem como uma das causas condicionadoras a natureza do trabalho que executa e a qualidade dos instrumentos e processos que emprega. Sendo assim, essa clareza será dada por um processo educativo no qual a periferia, e neste caso o Brasil, consolide uma educação de projeto de nação desenvolvida, onde a alfabetização seja plena. Desse modo, não basta o país alcançar o grau de uma nação totalmente alfabetizada no papel, mas na realidade ser "alfabetizada em escala zero". Segundo Vieira Pinto, o analfabetismo (fato negativo) não é uma essência por si só, mas sim um grau do próprio alfabetismo, havendo assim, a necessidade de se sobressair, desligar-se desta realidade enganosa, ocorrendo desse modo um enfrentamento de uma consciência crítica com a ingênua.

O trabalho realizado pelas massas constrói suas próprias visões de mundo. Nas formas inferiores, nos trabalhos subalternos, explorados e humildes, o trabalhador não obtém noção total de sua realidade, pois não the são fornecidos ferramentas que lhe construam condições de percepção e de modificação de suas realidades. Para tal, há a necessidade de mobilização de suas existências, havendo um acesso pleno às técnicas vigentes.

Vieira Pinto recusa a expressão "era tecnológica", como se não existisse susseções de eras e invenções. Para ele, o homem não seria humano se não vivesse sempre numa era tecnológica. Logo, a raiz deste debate confronta os diferentes níveis de tecnologias, através da apropriação indébita que as nações ricas fazem das riquezas do mundo subdesenvolvido ou periférico. Esse mundo contemporâneo concretiza-se através da diferença de acesso aos avanços tecnológicos. O conceito de "era tecnológica" se tornou, portanto, um conceito 
ideológico de expressão de dominação por parte dos grupos dominantes, onde a cultura do consumo dirigido é justificada por metáforas, as quais consolidam os desníveis dos países desenvolvidos entre subdesenvolvidos.

Através destes argumentos metafóricos, o conceito serve de anestésico para ambas as classes sociais sem distinção, ricos e pobres fazem parte da mesma dinâmica, dentro desse endeusamento da "era tecnológica". Neste momento, pode-se observar aonde 0 autor quer chegar com essas argumentações: para a visualização das disparidades entre o centro e periferia é preciso romper o circulo infernal de uma falsa totalidade, onde todos estão inseridos e todos participam ao mesmo tempo das coisas e decisões sobre futuro de cada nação, através da ciência unificada e da técnica. Para ele, o mundo chegou a um grau no qual não poderá recusar, mas também não poderá abrir mão, de projetar na autonomia $\mathrm{e}$ participação deste contexto, sem estar de fora desta dinâmica de conhecimentos e consciência de mundo.

A compreensão da técnica e da sua influência diante da mecanização do trabalho agora entra em um novo estágio, o do conhecimento. 0 que é produzido e que atualmente se consome faz parte da estrutura e dinâmica da economia e política da sociedade. Dessa forma, surge a idéia de que os homens nada criam, nada inventam, nem fabricam, que não sejam expressões das suas necessidades, a fim de resolver as contradições com a realidade. Portanto, nenhuma filosofia da técnica, e muito menos qualquer espécie de futurologia, será válida se não começar prever mudanças legítimas e naturais do modo de produção em vigor na sociedade, e tal desenvolvimento necessariamente conduz a fraturas e saltos qualitativos, pelos quais se instalam em certos movimentos novas formas de produção e reprodução.

Diante do mito da tecnologia, o homem projeta o seu ser não por especulações metafísicas, mas é mediante o trabalho que esse o realiza, e isso acontece através da transformação de realidades materiais criando condições de vida, "promovendo e estabelecendo novos vínculos produtivos com as forças e substâncias da natureza". Sendo assim, faz-se necessário saber a compreensão da divisão social do trabalho: 0 homem "desumanizado", "coisificado", perde sua capacidade de produção, de ser "produtor", sendo reduzido a mero consumidor. Nessas condições de apropriação, baseado no monopólio do trabalho, há uma apropriação do trabalho alheio.

A mediação entre 0 homem e a máquina explica-se sob a forma de trabalho automatizado e da invenção de máquinas reguladoras e diretoras de linhas de produção. Este é um tema de interesse de pensadores no mundo inteiro, no qual se ocupam com a relação homem e máquina. Esta relação coloca-nos diante de indagações na qual o próprio Vieira Pinto se questiona: será que é o homem o único ser a quem se possa atribuir à qualidade de ser pensante ou as máquinas atuais poderão ser também consideradas possuidoras de pensamento? 0 próprio autor responde dizendo que a compreensão sobre esse fundamento é nos anteciparmos à máquina, e chegar ao seu antecedente natural: o homem, o ser que cria $\mathrm{e}$ projeta. A máquina somente se justifica na sua base social como fruto do processo social e do pensamento do homem, ou seja, da cultura, uma criação do homem, resultado da complexidade crescente das relações sociais do processo de sua formação como ser biológico, em virtude do desenvolvimento da ideação reflexiva, do ato de inovar as operações que exerce sobre a natureza. A complicação do modo de vida dos homens em surgimento impõe-lhe a necessidade da ação coletiva na realização do seu ser, o que significa a passagem à etapa social da produção da cultura. Desse modo, a cultura constitui-se por efeito da relação produtiva que é indissociável do processo de produção e, neste sentido, ela é vista

Geografia Ensino \& Pesquisa, v. 15, n.1, p. 111 114, jan./abr. 2011

Alexandre Elesbão Bandeira 
como um bem de consumo que a sociedade, obrigatoriamente, mediante a educação, distribui a seus membros. Conforme o autor descreve, é nessa relação dialética contraditória que, no ato de produção, o homem afasta-se de sua criação, através do consumo dos bens que produziu e que agora os torna vivos. $O$ homem é ao mesmo tempo produtor e consumidor, e assim, no ato do consumo, cada classe irá satisfazer-se de acordo com o seu grau de aquisição, através de uma aparência de conforto, no qual cada classe esta inserida.

A história da técnica diz respeito à relação do homem com a natureza, onde o homem midiatiza uma relação de afastamento, através de dominação e domínio entre ambos e si próprio. Nada domina em essência o homem a não serem as leis da natureza e, acidentalmente, outro homem. "Do lado da natureza situam-se as forças físicas, enquanto do lado humano entram em ação as forças culturais, o conhecimento racional".

O homem de cada fase histórica desenvolve a técnica numa difusão continua de sobrevivência sobre a natureza. Não é a técnica o motor da história, mas sim, a necessidade permanente de criação e sobrevivência na qual o homem trava uma relação com a natureza, onde a ferramenta maior é o trabalho. A técnica é um patrimônio da espécie e sua função consiste em ligar os homens na realização das ações construtoras comuns no espaço- tempo, sem dominar o homem. Sendo o homem o único capaz de historicizar o tempo, ele sempre contornará qualquer problema de sua existência, desde que não sejam os fenômenos da natureza. Porém, é o homem que pode dominar outro homem através da técnica, mediante sua ideologização e, conseqüentemente, manipulação de outros segmentos sociais, o que resulta em uma anestesia social mediante a relação homem e técnica, e vice-versa. Assim, foram as técnicas do passado que justificaram e serviram aos regimes de produção escravista e que hoje recebem novas artimanhas e veredas de sua existência e racionalidade para apropriação das classes privilegiadas diante de grandes segmentos desassistidos, desfiliados.

É na relação do trabalho, e nos seus discursos, que a tecnologia é desassistida à grande parcela de indivíduos da sociedade humana. $O$ trabalho é o modo de ser do homem e o seu valor determinará a estrutura das sociedades. Portanto, toda essa discussão pertence, segundo o autor, a uma "tecno-estrutura", onde o valido é saber a quem pertence o Estado, a sociedade. Mediante isso, conclui-se que de nada adianta discursos de nacionalismo, estatização ou até mesmo privatização, se não soubermos a quem pertencemos. Caso isso ocorra, seremos sempre "paciente receptor".

\section{Correspondência}

Alexandre Elesbão Bandeira - General Bacelar 196 apt 107 centro, CEP: 96200-370. Rio Grande- RS- Brasil.

E-mail: aebandeira@gmail.com

Recebido em 10 de março de 2011. Aprovado em 20 de março de 2011.

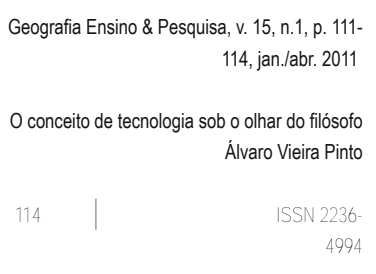

